\title{
Chris Berry and Mary Farquhar, China on Screen: Cinema and Nation
}

\section{Kristof Van Den Troost}

\section{OpenEdition}

12 Journals

Édition électronique

URL : http://journals.openedition.org/chinaperspectives/2693

DOI : $10.4000 /$ chinaperspectives. 2693

ISSN : 1996-4617

Éditeur

Centre d'étude français sur la Chine contemporaine

Édition imprimée

Date de publication : 15 décembre 2007

ISSN : 2070-3449

Référence électronique

Kristof Van Den Troost, "Chris Berry and Mary Farquhar, China on Screen: Cinema and Nation », China Perspectives [En ligne], 2007/4 | 2007, mis en ligne le 09 avril 2008, consulté le 21 septembre 2020. URL : http://journals.openedition.org/chinaperspectives/2693 ; DOI : https://doi.org/10.4000/ chinaperspectives.2693

Ce document a été généré automatiquement le 21 septembre 2020.

(C) All rights reserved 


\title{
Chris Berry and Mary Farquhar, China on Screen: Cinema and Nation
}

\author{
Kristof Van Den Troost
}

1 During the last decade, books and papers on Chinese cinema have multiplied almost exponentially. One of the major problems engaged in those writings has been the very question of how to write on Chinese cinemas. Should one include the works of Hong Kong and Taiwan filmmakers? What about "transnational" films such as Crouching Tiger, Hidden Dragon (2000)? And can we still speak of a "Chinese national cinema"?

2 In their new book, Berry and Farquhar convincingly argue that "the national informs almost every aspect of the Chinese cinematic image and narrative repertoire" (p.2). However, the old "national cinemas" approach, which took the national for granted as something known, can no longer be adequately used to study the national in Chinese cinema. Instead, Berry and Farquhar suggest approaching the national as "contested and construed in different ways" and focusing on "cinema and the national as a framework within which to consider a range of questions and issues about the national" (p. 2). After establishing this framework, the authors go on to investigate the intersections of the national with various topics.

Chapter 2 examines time in the cinema. Berry and Farquhar argue that cinematic time and the national are configured in at least three major ways. National history films, such as four Opium War films made at different times in different ideological contexts, produce time as linear, progressive, and logical. A second group of films looks back critically at the past by mixing fact and fiction, with Hou Hsiao-hsien's City of Sadness (1989) and Chen Kaige's Yellow Earth (1984) serving as examples. The final configuration involves haunting time and includes films such as Wong Karwai's In the Mood for Love (2000), which demonstrate how the persistence of non-modern time undermines modernity and the linear logic of national progression.

4 Chapters 3 and 4 analyze two distinctively Chinese cinematic modes, the operatic and the realist, "whose variations must be explained within contexts of different formations of the national" (p. 11). The operatic mode, which Berry and Farquhar call "shadow opera," represents an "ongoing sinicization of cinema" (p. 48), and is 
therefore a culturally nationalist mode. However, it was realism that was adopted as the aesthetic counterpart of the quest to make China a modern nation-state (p. 77). Realism merged with melodramatic conventions to offer different views of the national through the metaphors of family and home. Berry and Farquhar then move on to discuss the intersection of gender and nation in chapters 5 and 6 . In chapter 5 , the "way a Chinese woman should look" is analyzed in relation to different configurations of modernity and the nation state. Through the star images of Ruan Lingyu, Xie Fang, Gong Li, and Maggie Cheung, three senses of the look are examined: the look of the camera upon the woman, the woman's subjective look, and how she looks before others. Chapter 6 on "how Chinese men should act" then investigates the Confucian codes of loyalty, filiality, and brotherhood, which continue to operate in Chinese cinema as "mythic symbols of national identity, ideal masculine behaviour, and institutional governance" (p. 136). The chapter discusses the play with these codes that "link contemporary struggles over masculine identity with various constructions of the colonial and the national in Hong Kong and China , respectively" (p.12) in films such as Drunken Master II (1993), The Killer, (1989) and Hero (2002).

In chapter 7 on ethnicity in Chinese cinema, the focus is on some less noticed configurations of ethnicity and nationality. An analysis of Ang Lee's The Wedding Banquet (1993) illustrates how the good foreigner is accommodated within the Chinese family. Next, Berry and Farquhar discuss a second pattern that appeared in the People's Republic after 1949, where minorities were depicted as "little brothers" to the Han Chinese "big brother" in order to reduce tension between the ethnic and territorial nation. Finally, the appearance of intra-Chinese distinctions in Taiwanese and Hong Kong films after the influx of mainland refugees is examined.

The last chapter reflects on how the national and transnational interact. With the intention of offering a more nuanced view of Chinese cinema's export successes, the authors ask what price has been paid for them. Three transnational projects are examined: Bruce Lee's borrowing from Hollywood in revitalizing Chinese masculinity, the propriation of the blockbuster concept in the attempt to counter Hollywood domination, and the rebirth of the Singaporean film industry through its use of the transnational cinema market.

7 The framework proposed by Chris Berry and Mary Farquhar allows them to engage many of the topics discussed in relation to Chinese cinema in the last few years. Although certainly innovative, one sometimes wonders whether some films can convincingly be discussed in terms of the national - the link between a film such as In the Mood for Love and the national seems somewhat farfetched to say the least. Nonetheless, by approaching their topics from new angles, China on Screen: Cinema and Nation offers not only a good overview of what has been published on the topic in the past in both China and the West, but also an excellent addition to these analyses. Written in a clear and entertaining style, with short plot outlines of the films inserted in the main text, this book is as suitable for people just entering the field as for specialized scholars. 